\title{
ЗАСОБИ ДИСТАНЦІЙНОГО НАВЧАННЯ У ФОРМУВАННІ МОВНОЇ КОМПЕТЕНТНОСТІ ОФІЦЕРІВ
}

\begin{abstract}
Анотація. Сучасні світові тенденції до поширення технологій дистанційного навчання відкрили нові перспективи розвитку освітнього процесу. I тому раціональне поєднання таких технологій з вже існуючими методами викладання в теперішніх умовах стають запорукою успішної навчальної діяльності як викладачів, так і слухачів. Метою статті є розкриття поняття «засобів дистанційного навчання», уточнення споріднених понять, визначення їх переліку і рекомендацій щодо фрормування мовної компетентності офріцерів. Для досягнення ціеї мети використовувались теоретичні методи дослідження: аналіз літератури, систематизація, узагальнення, моделювання та наукова інтерпретація. Результати дослідження. Вивчення стану застосування засобів та технологій дистанційного навчання (ДН) в закладах вищої освіти дозволило виявити, що ДН у Національній гвардії України може застосовуватися в різних формах і буде інтегровано в основні програми навчання та професійної підготовки. Ми дійшли до висновку, що до засобів ДН можна віднести: окремі технології, засоби цифрових технологій, засоби роботи з інформацією (гіпертекст, мульти- та гіпермедіа), програмні засоби навчання, засоби ІКТ. У результаті аналізу наукових праць виділено такі технології дистанційного навчання для мовної підготовки офіцерів НГУ як Busuu, LinguaLeo, Kahoot, Pocket, Studyblue, Animoto, Words With Friends, Grammar Up, ENpodcast, Lingvo словник, BBC Learning English, British Council LearnEnglish, Quizlet, Duolingo, Lingualeo, engVId, Memrise, TEDtalks, Loyal books, FlipGrid та багато інших. I хоча застосування впровадження технологій дистанційного навчання в навчальну діяльність ВНЗ в Україні супроводжуеться низкою невирішених проблем, кожна 3 них, і тим більше методи їх вирішення, вимагають глибокого і всебічного вивчення i можуть бути основою подальшого дослідження розвитку і впровадження дистанційного навчання. Узагальнюючи різні точки зору, ми дійшли висновку, що найбільший ефект засоби дистанційного навчання можуть давати в разі використання їх з варіантами комплексу технологій дистанційного навчання на різних етапах засвоєння.
\end{abstract}

Ключові слова: засоби дистанщійного навчання, технології дистанщійного навчання, мовна компетентність, формування мовної компетентності, система військової освіти.

Liutyi Volodymyr National Academy of the National Guard of Ukraine

\section{DISTANCE LEARNING RESOURCES FOR DEVELOPING OFFICERS' LANGUAGE COMPETENCIES}

Summary. Modern world trends in the distance learning technologies and resources have opened up new perspectives for the development of the educational process. Therefore, the rational combination of such technologies with existing teaching methods in the current environment become the key to successful learning activities for both teachers and students. The purpose of the article is to reveal the concept of "distance learning resources", clarify related concepts, and determine their list and recommendations for developing officers' language competencies. To achieve this goal, theoretical research methods were used: literature analysis, systematization, generalization, modeling and scientific interpretation. The results of the research were the following. The research of the use of the distance learning resources and technologies in higher education institutions revealed that the distance learning could be used at the National Guard of Ukraine in various forms and will be integrated into the main education and training programs of. We came to the conclusion that the distance learning resources can include following certain technologies, resources of digital technologies, information source matters (hypertext, multimedia and hypermedia), software, learning tools as well as information and communication technology. As a result of the analysis of scientific researches such distance learning technologies for language training of the National Guard of Ukraine officers were identified as Busuu, LinguaLeo, Kahoot, Pocket, Studyblue, Animoto, Words With Friends, Grammar Up, ENpodcast, Lingvo dictionary, BBC Learning English, British Council Learn English, Quizlet, Duolingo, Lingualeo, engVId, Memrise, TEDtalks, Loyal books, FlipGrid and many more. Although the use of distance learning technologies in the education at the universities in Ukraine is accompanied by a number of unresolved problems, each of these problems, and especially the methods of solving them, require in-depth and comprehensive study and can be the basis for further research and development of distance learning. Summarizing different points of view, we came to the conclusion that the greatest effect of distance learning resources can give in the case of using them with a set of distance learning technologies at different stages of learning.

Keywords: distance learning resources, distance learning technologies, language competence, development of language competence, military education system.

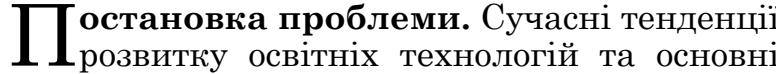
напрямки державної політики у цій сcрері потребують спрямування зусиль на розвиток дис- танційного навчання у Національній гвардії України як одного з найдієвійших інструментів реалізації моделі безперервного навчання офріцерів. Дистанційне навчання у Національній

${ }^{1}$ ORCID: https://orcid.org/0000-0003-0235-2475 
гвардії України може застосовуватися в різних формах і буде інтегровано в основні програми навчання та профресійної підготовки. Відповідно до оперативної цілі 5.2 Стратегічного оборонного бюлетеня України, затвердженого Указом Президента України від 06 червня 2016 року № 240/2016, передбачено впровадження технологій дистанційного навчання в освітній процес 3 метою удосконалення системи військової освіти та підготовки кадрів.

Аналіз останніх досліджень і публікацій. Положення про ДН [1] визначає ДН як індивідуалізований процес набуття знань, умінь, навичок і способів пізнавальної діяльності людини, який відбуваеться в основному за опосередкованої взаємодії віддалених один від одного учасників навчального процесу у спеціалізованому середовищі. Отже, џифрова та психолого-педагогічна компетентності викладачів е необхідною умовою реалізації ДН. За Концепцією розвитку дистанційної освіти в Україні дистанційна освіта - це форма навчання, рівноцінна 3 очною, вечірнього, заочною та екстернатом, що реалізуеться, в основному, за технологіями дистанційного навчання [2]. У посібнику «Організація та використання технологій дистанційного навчання у Збройних Силах України» [3] особливістю дистанційної форми навчання в ЗСУ вважається їі застосування у поєднанні з очною (денною, вечірньою) та заочною формами навчання, коли технології ДН використовують обмежено як засіб оновлення змісту й методів навчання та розширення доступу слухачів очної (заочної) фрорм навчання до освітніх ресурсів ВВНЗ, держави та інших країн. Насправді мова йде про дистанційне навчання за своєю сутністю з обмеженнями, які пов'язані із використанням інфрормації із обмеженим доступом або ту, яка містить в собі військову або державну таємницю. Тобто не на всіх навчальних дисциплінах може бути застосоване ДН, а тільки на тих, що не містять ані військової ані державної таємниці.

Виділення не вирішених раніше частин загальної проблеми. Слідуючи вимогам МОН щодо організації ДН, в пункті 1.16. Положення про організацію освітнього процесу в Національній академії Національної гвардії України [4, с. 13] наголошуеться на: створенні умов для набуття здобувачами вищої освіти комунікативної компетентності іноземною мовою на необхідному рівні та постійному вдосконаленні змісту навчання, орієнтації на новітні технології та методики навчання, максимальне використання в освітньому процесі технологій дистанційного навчання і сучасних інформаційно-аналітичних систем. А відповідно до п. 15.1.15. цього ж Положення однією із форм підвищення кваліфрікації в Академії є заочна (дистанційна, мережева) [4, с. 231], одним із основних завдань якої є застосування інноваційних технологій реалізації змісту навчання, що передбачає запровадження дистанційних та інформаційно-комунікативних технологій навчання.

Мета статті. Розкриття поняття «засоби дистанційного навчання», уточнити споріднені поняття із цим, визначити їх перелік і рекомендації щодо формування мовної компетентності офріцерів.
Методи дослідження. У статті використано систему загальнонаукових методів і прийомів наукового пізнання: аналіз, синтез, порівняння, класифрікація, систематизація й індуктивне узагальнення релевантних до теми та мети дослідження теоретичних даних, які поєднали науково-категорійний аналіз понять «засоби дистанційного навчання», «технології дистанційного навчання», «мовна компетентність».

Виклад основного матеріалу. Існує дуже велика кількість визначень дистанційного навчання, а також засобів та технологій дистанційного навчання. Ми пропонуемо розглянути деякі 3 них, що представляють для нас найбільший дослідницький інтерес у межах порушеної проблематики дослідження. Нами було визначено ДН як окремий вид навчання з особливою формою навчання, яка передбачає екстериторіальну взаємодію суб'єктів навчання із використанням психолого-педагогічних, інформаційно-комунікативних технологій та цифрових індрормаційно-освітніх ресурсів, дозволяе проводити інтерактивні заняття 3 різною кількість людей, надаючи можливість у індивідуальному спілкуванні між об’єднаних спільною метою суб'єктами та об'єктами навчання синхронно та асинхронно, реалізовуеться в спеціалізованому середовищі за допомогою технічних засобів зв'язку і характеризуеться інтенсифікацією, активізацією і індивідуалізаціею навчання [5]. Виникае питання про поняття «засоби дистанційного навчання». В. І. Лозова розглядає «засіб навчання» як те, за допомогою чого здійснюеться навчання: книги, словники, наочні посібники, технічні засоби тощо [6, с. 313]. На їі думку, засобами програмованого (керованого) навчання, до якого належить і дистанщійне, можуть бути: програмовані підручники, за допомогою яких здійснюеться весь цикл засвоєння знань; збірники задач і вправ, які побудовані в основному на завданнях 3 варіативними відповідями; зошити 3 друкованою основою; перфокарти, сигнальні картки; контролюючі машини; технічні засоби навчання (ТЗН). На думку П. Стедраненко [7], в якості засобів реалізації технології дистанційного навчання доцільно використовувати: комп'ютерні технології (навчальні комп'ютерні програми, електронні підручники, моделі, програми інтерактивного відео i мультимедіа); системи телекомунікації (телеконференції, відеокондеренції, електронна пошта, відеотекст, робота 3 базами даних та базами знань у режимі прямого доступу). Як зазначено у Листі МОН України [8] відповідно до пунктів 6, 11, 12 розділу I, пунктів 3, 5 розділу IV Положення (Положення про дистанційну форму здобуття повної загальної середньої освіти, затвердженим наказом МОН від 08 вересня 2020 року № 1115) заклад освіти у рамках власної автономї має можливість обирати (схвалювати педагогічною радою закладу освіти) конкретні електронні освітні платформи, он-лайн сервіси та інструменти, за допомогою яких організовуеться освітній процес під час дистанційного навчання (Moodle, Google Classroom, Zoom тощо). Тому під сучасними засобами ДН ми розуміємо: конкретні електронні освітні платформи, он-лайн сервіси та інструменти, за допомогою яких організовуеться 
освітній процес під час дистанційного навчання (Moodle, Google Classroom, Zoom тощо), збірники задач і вправ; робочі зошити, комп'ютерні технології (навчальні комп'ютерні програми, електронні підручники, моделі, програми інтерактивного відео і мультимедіа); системи телекомунікації (телеконференції, відеоконференції, електронна пошта, відеотекст, робота з базами даних та базами знань у режимі прямого доступу), тощо. Засоби дистанційного навчання передбачають застосування своїх окремих технологій. Розкриемо найбільш популярні з них (табл. 1).

М. Садовський [19] розглядає можливість застосування деяких CMS (content management system) - систем управління змістом ДН як комерційні, так і безкоштовні: Joomla, WordPress, Drupal, 1C: Бітрікс, MODx, AMIRO.CMS, PHPShop, де Wordpress являе собою потужну платформу для ведення блогів, проста для розуміння та освоєння пересічним користувачем, але недостатньо функціональна для виконання завдань навчального спрямування; Drupal система управління контентом, містить велику кількість готових модулів, за допомогою яких можна зробити: фоотогалерею, файлообмінник, блоги, форуми і т.д.; Joomla - вільно поширювана система управління контентом з відкритим кодом, який можна використовувати для впровадження власних функцій в систему. Беручи до уваги вищезазначені цілі та завдання систем дистанщійного навчання, можна зробити наступні висновки: приведені CMS-системи, не зовсім адаптовані під особливості організації навчального процесу, тобто, їхня реалізація можлива, але буде вимагати високої кваліфікації розробника навчальної системи, суттевої переробки змісту універсальних модулів та шаблонів; комерційність деяких модулів та шаблонів не дозволить адаптувати їх під функції та задачі навчального процесу; ускладнення в роботі педагогічних працівників при підготовці навчального курсу, їхня фахова підготовка повинна передбачати знання комп'ютерних індормаційних технологій, основ Web-програмування, або, у разі відсутності таких знань, реалізація навчальних курсів тільки через посередництво кваліфікованого інженерно-технічного персоналу супроводження системи дистанційного навчання; відсутність модулів та шаблонів, що є характерними виключно для навчального процесу, наприклад, тестові модулі оцінки знань, електронні навчальні журнали, модулі побудови рейтингового ряду успішності.

Одним із представників подібних систем виступае система Moodle, що розповсюджуеться за ліцензією GNU GPL, тобто е вільним програмним забезпеченням і поширюеться безкоштовно. За своїми функціональними можливостями, простоті і зручності використання задовольняе більшості вимог, що пред'являються до систем дистанційної освіти. Такі e-learning системи часто називають системами управління навчанням (Learning Management Systems - LMS) або віртуальними освітніми середовищами (Virtual Learning Environments - VLE). На думку К. Га-

Засоби та технології ДН

Таблиця 1

\begin{tabular}{|c|c|}
\hline Засоби ДН & Технології ДН \\
\hline $\begin{array}{l}\text { Засоби цифрових } \\
\text { технологій } \\
\text { [9] }\end{array}$ & $\begin{array}{l}\text { - інтерактивні плакати (Glogster, Cacoo, Thinglink, Padlet); } \\
\text { - мультимедійні презентаціï (PowerPoint iз naкema Microsoft Office, Open Office } \\
\text { Impress, Prezi, AppleKeynote, Haiku Deck, Slides, Projeqt); } \\
\text { - інтелектуальні карти (Freemind, Coogle, Xmind, MindMeister, BubblUs, MindMup 2, } \\
\text { iMindMap); } \\
\text { - інфографріка (Piktochart, Visual.ly, Many Eyes) [9]. }\end{array}$ \\
\hline $\begin{array}{l}\text { Засоби роботи } \\
\text { з інформацією: } \\
\text { гіпертекст, мульти- } \\
\text { та гіпермедіа } \\
{[10 ; 11]}\end{array}$ & $\begin{array}{l}\text { - кейс-технологія; } \\
\text { - TV-технологія; } \\
\text { - мережні технології; } \\
\text { - Internet-технологія із сполученням з CD-ROM-засобами; } \\
\text { - Web-CD технології [10; 11]. }\end{array}$ \\
\hline $\begin{array}{l}\text { Програмні засоби } \\
\text { навчання } \\
\text { [12] }\end{array}$ & $\begin{array}{l}\text { - системи комп'ютерного тестування; } \\
\text { - системи віртуального діалогу; } \\
\text { - компютерні тренажери; } \\
\text { - електронні підручники; } \\
\text { - мультимедійні словники й довідники; } \\
\text { - віртуальні лінгафонні кабінети, лабораторії; } \\
\text { - хмароорієнтоване навчальне середовище [12]. }\end{array}$ \\
\hline $\begin{array}{l}\text { Засоби ІКТ } \\
{[13]}\end{array}$ & $\begin{array}{l}\text { - інформаційні ресурси; } \\
\text { - інформація, знання за фрахом; } \\
\text { - програмне забезпечення адміністративно-педагогічного призначення; } \\
\text { - прикладне програмне забезпечення; } \\
\text { - навчання окремих видів мовленневої діяльності і їх сукупності; } \\
\text { - комунікаційні ресурси; } \\
\text { - компютерна техніка; } \\
\text { - телекомунікаційні системи; } \\
\text { - мережі передачі даних; } \\
\text { - інтернет [13]. }\end{array}$ \\
\hline \multirow[t]{2}{*}{$\begin{array}{l}\text { Засоби організації ДН } \\
{[14]}\end{array}$} & $\begin{array}{l}\text { - Платформа дистанційного навчання MOODLE [15; 16; 17; 18]; } \\
\text { - Програмне середовище Adobe Captivate [15]; } \\
\text { - Платформа Tеams [16; 17]; } \\
\text { - Платформа ДН Google Classroom [18]; } \\
\text { - Платформа ДН Sakai [18]. }\end{array}$ \\
\hline & $\begin{array}{l}\text { Універсальні системи керування вмістом (CMS) [19]: Joomla, WordPress, Drupal, 1C: } \\
\text { Бітрікс, MODx, AMIRO, CMS, PHPShop. }\end{array}$ \\
\hline
\end{tabular}


риленко [20], основними платформами, на яких викладачі університету здійснювали навчання, були Moodle i Google Classroom. Он-лайн-зустрічі зі студентами проводилися переважно на платdopмax Zoom i Google Meet. Також досить популярними були допоміжні ресурси для створення тестових завдань на зразок Classtime, Kahoot та ін. Основними інструментами, використаними викладачами університету для дистанційного навчання, стали: віртуальні класи для систематизації груп на зразок Moodle, Google Classroom; спеціальні платформи для проведення регулярних занять у реальному часі наближених до роботи в реальній аудиторії (Zoom, Google Meet, Skype); он-лайн-ресурси для створення тестів, різноманітних опитувань, завдань і матеріалів для студентів (Classtime, Kahoot, LearningApps та ін.); наявні підручники у цифррових фрорматах; мультимедійні відео та аудіо матеріали, інші ресурси, сумісні з обраним віртуальним класом. Ю. Грицук [21] найбільш ефеективними технологіями вбачає Moodle, BigBlueButton, Teams та Zoom. У своїх порадах Д. Волинець, спеціалістка з питань стратегічного розвитку та проектного менеджменту, методолог та тренерка проекту «Креативна Молодь Змінить Україну» радить: «Зустрічі он-лайн - це певний вихід із зони комфорту, який нам також дає змогу розвиватися та покращувати свої м'які навички, ми стаємо більш гнучкими, краще справляємося 3 умовами невизначеності та легше сприймаємо нове. Всі наші напрацювання залишаються зафріксованими і доступними для кожного з членів команди (google docs, miro), тоді як на живих тренінгах багато цінної інформації залишається на аркушах фрліпчарту» [22].

Деякі науковці (К. Конвей (C. Conway), С. Хappic (S. Harris) та ін.), характеризуючи цифрові технології, використовують це поняття як синонім комп'ютерним технологіям та зазначають: будь-яка інформація, яка використовуеться на комп'ютері або розповсюджується на комп'ютері, відома як циоррова технологія. Серед прикладів цифрових технологій вони наводять не лише комп'ютерні програми та програмне забезпечення, а також веб-сторінки та веб-сайти, включаючи соціальні медіа; дані та бази даних; цифровий звук, наприклад, тр3 та ін. [23]. Н. Воронова до цифрових технологій включає всі види електронного обладнання та програми, які використовують інформацію у вигляді числового коду [9]. Серед близьких до них понять: "Компютерні технологї̈» як узагальнена назва технологій, що відповідають за зберігання, передачу, обробку, захист та відтворення інформащії з використанням комп'ютерів. Поза комп'ютерних технологій неможливо уявити фрункціонування сучасного суспільства. Комп'ютери стають невід'ємним складником навчання, професійної діяльності, наукових досліджень, розваг та повсякденного життя; "Мультиледійні технологї̈" - різновид комп'ютерних технологій, що забезпечуе з'єднання декількох видів пов'язаної між собою інфрормації (текст, звук, фрото, малюнок, анімація, відео тощо) в єдиний блок; "Інбормаційні технологї̈», що поеднують в одному програмному продукті різноманітні види інформаційних ресурсів: тексти, ілюстрації, анімацію, аудіо- і відеоіндрормащію; "Інфборлаційно-колунікаиійні технологї (IKT)» як сукупність методів, виробничих процесів і програмно-технічних засобів, об'єднаних 3 метою збирання, опрацювання, зберігання і розповсюдження, інформації в інтересах її користувачів. ІКТ еволюціонували в цифрові технології, які наразі охопили всі сдери інформаційного суспільства [24; 25].

Таким чином можна зробити висновок, що питанням вивчення різноманітних цифрових технологій навчання займалися й продовжують займатися різні науковці. I всі вони приходять до висновку необхідності застосування таких технологій в освітньому процесі в сучасних умовах. А отже і розуміння цифрових/електронних освітніх ресурсів також є вимогою часу. В таблищі 2 наведено декілька тлумачень таких ресурсів.

Науковці М. Браун (M. Brown) [32], Г. Доббін (G. Dobbin), M. Линч (M. Lynch) [33] та ін. працюють над теоретичним і практичним забезпеченням відкритої освіти, яке вони називають ,цифровим освітнім середовищем нового покоління" (Next Generation of Digital Learning Environment (NGDLE), який має стати універсальною цифровою навчальною платформою для вчителів та учнів, викладачів та студентів, місцем розташування й надання програм, послуг навчання та інструментів управління навчанням.

У посібнику «Організація дистанційного навчання в школі» [14] визначається, що критерієм вибору інструментів для організації дистанційного навчання має бути відповідність поставленим методичним цілям, тобто те, наскільки певний сервіс чи ресурс уможливлюе досягнення очікуваних результатів навчання в дистанційному фрорматі. Так, до основних фрорм он-

Визначення цифрового/електронного освітнього ресурсу

Таблиця 2

\begin{tabular}{|c|c|c|}
\hline $\begin{array}{l}\text { № } \\
\text { 3/ח }\end{array}$ & $\begin{array}{c}\text { Автор та посилання } \\
\text { на джерело }\end{array}$ & Визначення \\
\hline 1. & Л. Гаврілова [26] & $\begin{array}{l}\text { „електронний освітній ресурс (ЕОР)” це освітній контент електронної формми, } \\
\text { який можна використовувати з допомогою електронних технічних засобів }\end{array}$ \\
\hline 2. & $\begin{array}{c}\text { A. Ель Мхоуті } \\
\text { (A. El Mhouti), М. Eppaдi } \\
\text { (M.Erradi), A. Насcех } \\
\text { (A. Nasseh) [27] }\end{array}$ & $\begin{array}{l}\text { цифрові освітні ресурси це мультимедійні та інтерактивні освітні продукти, } \\
\text { розроблені в умовах електронного навчання з урахуванням навчального, } \\
\text { дидактичного та технічного аспектів }\end{array}$ \\
\hline 3. & $\begin{array}{l}\text { P. Вуорікарi (R. Vuorikari), } \\
\text { P. Копер (R. Koper) [28] }\end{array}$ & цифрові освітні ресурси це веб-ресурси та цифрові освітні бібліотеки \\
\hline 4. & $\begin{array}{l}\text { Н. Бетчер (N. Butcher) [29], } \\
\text { Ст. Доунс (St. Downes) [30] }\end{array}$ & $\begin{array}{l}\text { Цифрові освітні ресурси це синонім „відкритих освітнім ресурсам” (Open } \\
\text { Educational Resources) тобто це цифрові навчальні та дослідницькі } \\
\text { матеріали [31] }\end{array}$ \\
\hline
\end{tabular}


лайн-комунікації відносять: відеоконореренції, фороми, чати, блоги, електронну пошту та анкетування, а також соціальні мережі, служби обміну миттевими повідомленнями та мобільні застосунки на кшталт Viber. Серед різноманіття веб-ресурсів МОН рекомендує:

- для організації дистанщійного навчання такі платформи як: Moodle, Google Classroom, Zoom;

- для проведення відеоконференцій: Microsoft Teams, Google Meet, Skype тощо;

- для оцінювання роботи класу в режимі реального часу: ClassDojo;

- для створення інтерактивних вправ: LearningApps.org;

- для створення інтерактивних навчальних додатків, які дозволяють вести аналітику навчального процесу і реалізовувати стратегії індивідуального підходу: Classtime;

- для створення комунікативного простору: Padlet, Google Classroom, Moodle тощо [14].

Серед різноманіття інструментарію цифррового навчання фрахівці МОН виділяють інструменти роботи 3 відео, он-лайн дошки, тести, практику та інструменти формувального оцінювання, інтерактивні сервіси миттевого опитування, інструменти цифрової творчості слухачів. Так, до цифрових інструментів роботи 3 відео, наприклад, відносять:

- для запису скрінкастів: Screencast-o-matic;

- для створення інтерактивних відео з запитаннями, вбудованими в хід ролика: Edpuzzle;

- для розміщення власних роликів та надання до них доступу через інтернет: Youtube.

Прикладами цифрових сервісів он-лайндошок є Jamboard та Miro.

Он-лайн-тести можна створювати в Googleформах, а також на спеціалізованих платформax, наприклад Classtime. Однією з найдоступніших платформ для створення практичних вправ є Learningapps, а для надання формувального зворотного зв'язку існуе спеціалізований сервіс Goformative. Цікаві можливості розробляти різноманітні інтерактивні вправи на основі фрлешкарток надають сайти Studystack та Quizlet. Poботу 3 використанням робочих зошитів, роботу 3 ними можна перенести в он-лайновий режим через сервіси Liveworksheets, Wizer чи аналогічні.

Популярними сервісами миттевих опитувань $€$ Kahoot, Mentimeter, Polleverywhere. Для демонстрації опанування певної теми 3 навчального матеріалу існують спеціалізовані платформи обміну відеороликами, на яких учні можуть завантажувати свої відеовідповіді, коментувати ïx, дискутувати (наприклад Flipgrid). Окрім відеороликів, об'єктами цифрової творчості учнів можуть бути: карти понять (Mindmeister); комікси (Storyboardthat); блоги (Blogger); програми (Scratch); інфрографріка (Canva); анотовані зображення (Thinglink); фрлеш-картки, власні тести тощо. Усі ці засоби і прийоми ДН можемо використовувати і в роботі з дорослими здобувачами освіти 3 такою ж метою, враховуючи їх вік і наявність довільної уваги і логічного мислення.

Серед численної кількості веб-ресурсів Міністерство освіти і науки виділило перелік он-лайнресурсів для вчителів англійської, німецької та фрранцузької мов, які були надані Коорди- наційним комітетом 3 підтримки вчителів сучасних іноземних мов в умовах редорми "Нова українська школа" [34]. Так, для подолання викликів сьогодення в умовах карантину Координаційний комітет пропонує вчителям он-лайнресурси Британської Ради для покращення навчання англійській мові та активного залучення учнів до процесу учіння [35]. Окремо серед ресурсів Британської Ради був виділений перелік інтернет-ресурсів для підготовки викладачів:

1) практичні поради та ідеї щодо використання платформ дистанційного навчання - The Remote Teaching Tips;

2) правила безпеки при користуванні он-лайн ресурсами - Keeping your learners safe online;

3) поради 3 організації дистанційних занять з студентами різних вікових груп: практичні peсурси, плани уроків тощо - Teaching different age groups;

4) низка різноманітних коротких курсів для вчителів на FutureLearn;

5) тематичний блог для вчителів: дистанщійне навчання - Teacher blogs for the period April June 2020;

6) Публікації «Інновації в освіті: дистанційне навчання» - Publication Innovations in Education: Remote Teaching.

Можна додати до переліку ресурсів і українські платформи та ресурси для самоосвіти вчителів [36]:

1) український громадський проект масових відкритих он-лайн-курсів «Prometheus»;

2) Ukrainian English Language Teacher Learning Platform;

3) студія он-лайн-освіти EdEra;

4) освітній проект «На Урок»;

5) портал безперервного навчання СуXaPi;

6) вебінари 3 mozaBook та mozaWeb від EdPro.

Такий освітній портал як Pearson Ukraine пропонує [37]:

1) дистанщійне учіння та навчання;

2) вебінари та відео тренінги для вчителів англійської мови;

3) ресурси для вчителів;

4) ресурси для учнів;

5) освітній проект: уроки наживо.

А також Британська рада пропонуе он-лайнресурси для навчання англійській мові:

1) розповіді про Британію - Britain is great;

2) вправи на розвиток аудіювання та лексики: Word on the street (рівень B1, B2); Big City Small World (рівень B1); Audio zone; How to ... section;

3) вправи на розвиток говоріння - Practicing vocabulary;

4) вправи на розвиток читання: Magazine articles, Entertaining short stories;

5) вправи на розвиток граматики: Grammar; Practicing grammar; Vocabulary, spelling and grammar games;

6) вправи на розвиток всіх мовних компетентностей - Developing skills: listening, reading, writing, speaking;

7) вивчення різних тем з використанням відеофрільмів - Video zone;

8) вправи на практичне використання мови Podcasts.

Існуе і низка інших веб-ресурсів, які дозволяють опанувати іноземну мову дистанційно. Та- 
ким ресурсом є наприклад Express Publishing, де розміщені матеріали як для підготовки вчителів, так і для навчання студентів, а саме безкоштовні ресурси для вчителів від видавництва: робочі аркуші, картки, аудіо записи, портфоліо та багато іншого. Для навчання сприймання на слух на рівні А2 - В1, використання планів уроків, проведення формувального оцінювання існує ресурс «Folio D». Значний обсяг інфрормації щодо підготовки вчителів та навчання студентів пропонуе інтернет-ресурс «English: Cambridge University Press». Тут пропонується навчання студентів різних вікових груп та підготовка до складання кембриджських екзаменів.

Oxford University Press пропонуе наступний перелік навчального контенту як для викладачів так і для студентів:

1) навчаємося вдома: вебінари, блоги, корисні поради, ідеї, завдання та інше;

2) вчительські спільноти, вебінари, підписка на професійні розсилки, домашне читання тощо;

3) оцінювання: активності, які допомагають учням продемонструвати те, що вони знають;

4) адаптивне тестування у вивченні англійської мови;

5) оцінювання глобальних умінь;

6) створення тестів для підлітків;

7) серія вебінарів для вчителів на тему оцінювання.

С. Романюк [18] розмежовуе поняття «дистанційна освіта», «платформа дистанційного навчання», «он-лайн-сервіс» та виділяе найперспективніші ресурси для побудови ефрективної методики дистанщійного навчання іноземної мови, зокрема платформи дистанційного навчання Moodle, Google Classroom, Sakai та он-лайнсервіси Busuu, LinguaLeo, Lang-8. Детальний аналіз трьох виділених платформ дистанційного навчання (Moodle, Google Classroom, Sakai) показав, що усі з них підходять для розробки методики навчання іноземної мови, оскільки мають усі фрункції, які необхідні для забезпечення ефективного формування навичок та вмінь читання, говоріння, аудіювання та письма, а отже, вибір однієї з них повністю залежатиме скоріше від персональних вподобань кожного окремого викладача. Он-лайн-сервіси Busuu, LinguaLeo, Lang-8 є корисними ресурсами для організації самостійної роботи студентів, проте жоден 3 них не $е$ ідеальним, оскільки не забезпечує належного розвитку усіх необхідних навичок та вмінь. Проведений нами методичний аналіз цих сервісів показав, що Busuu доречно рекомендувати для організації самостійної роботи з говоріння, LinguaLeo - для розвитку навичок і вмінь аудіювання та читання, a Lang-8 - для навчання письма іноземною мовою.

На основі теоретичного аналізу джерел було визначено, що дистанційний курс з англійської мови професійного спрямування має відповідати таким вимогам: мати чітку структуру; сприяти розвитку всіх видів мовленневої діяльності студентів; містити фрахові тексти; відповідати профресійним потребам студентів; бути узгодженим 3 навчальною та робочою програмами. У немовному ВНЗ універсальною дидактичною одиницею продесійно-орієнтованого навчання $є$ автентичний фоховий текст, який слугує мате- ріалом для організації навчального спілкування. Від змісту тексту залежить результативність засвоєння термінологічної лексики, тому що тексти за фрахом є джерелом словникового запасу студентів/курсантів, прикладом вживання фахової лексики у контексті. Послідовність операцій у процедурі відбору професійної лексики містить такі етапи: вивчення тем, сфер і ситуацій, пов'язаних з майбутньою продесією студента; пошук і підготовка текстових автентичних матеріалів; обробка та систематизація дібраної термінологічної лексики; переклад термінів на українську мову; створення словника мінімуму фрахової лексики [38].

Продовжуючи думку щодо підготовки спеціаліста із використання сучасних технологій навчання, не можна оминути японську технологію Кайдзен, що базуеться на постійному, безперервному процесі розвитку та вдосконалення творчо-конструктивної діяльності особистості для підвищення кваліфрікації. Адже, за науковими розвідками [39], ця технологія дає можливість як очно, так i дистанщійно розвинути творчо-конструктивну взаємодію, підготувати конкурентоспроможного фрахівця, що у своїй професійній діяльності виявлятиме креативність, профресіоналізм та здатність приймати конструктивні рішення.

Зазначимо, що засоби ДН мовній компетентності можна класифрікувати за метою навчання (засвоєння граматики, орфографії, лексики, синтаксису тощо), видами мовної діяльності (слухання, говоріння, письмо, читання), етапами засвоєння нового матеріалу (формування мотивації до засвоєння і цілепокладання, сприйняття нового, усвідомлення та розуміння нового, закріплення нового, застосування на практиці нового, самоконтроль і самооцінка засвоєного). Можна визначити їх співвідношення таким чином (рис. 1):

Зазначимо, що в залежності від віку і підготовки здобувачів освіти, їх рівня освіти і володіння іноземною мовою, видів мовної діяльності, підготовки викладачів до використання засобів ДН, можливостей ЗВВО необхідно використовувати різні засоби ДН на різних етапах засвоєння.

Висновки. Отже, нами уточнено визначення засобів ДН в мовній підготовці офіцерів, технологій та платформ ДН офріцерів. Вивчення стану застосування засобів та технологій дистанційного навчання в закладах вищої освіти дозволило виявити, що у Національній гвардії України ДН може застосовуватися в різних формах і буде інтегровано в основні програми навчання та проdресійної підготовки. Ми дійшли до висновку, що до засобів ДН можна віднести: окремі технології застосування засобів ДН, засоби цифррових технологій, засоби роботи з інфрормацією (гіпертекст, мульти- та гіпермедіа), програмні засоби навчання, засоби IКТ, засоби організації. Виявлено, що найбільший ефект дистанційне навчання може давати в разі використання його на різних етапах засвоення.

У подальших дослідженнях планується вивчити і запропонувати шляхи впровадження i/чи розвитку виділених перспективних інфрормаційних технологій для удосконалення результатів застосування дистанційних технологій у практиці мовної підготовки офіцерів НГУ. 
Слово вчителя, підручник, кінофільми, картини, карти, таблиці та інший наочний матеріал, моделі, історичні та географічні карти, графіки, діаграми, спеціальні технічні засоби навчання (ТЗН): дидактична техніка, аудіовізуальні засоби, екранні посібники статичної проекції, окремі посібники динамічної проекції, фонопосібники, відеозаписи, радіо- і телевізійні передачі; комп'ютери, електронні словники, електронні підручники, аудіовізуальні навчальні посібники, електронні версії друкованих словників та посібників. BYOD, адаптивне навчання, віртуальне навчальне оточення, віртуальний клас, індивідуалізоване навчання, мобільне навчання, «Хмарне» навчання, онлайн-сторітеллінг, перевернутий клас, система управління навчальним процесом, змішане навчання, асинхронні засоби, синхронні засоби.

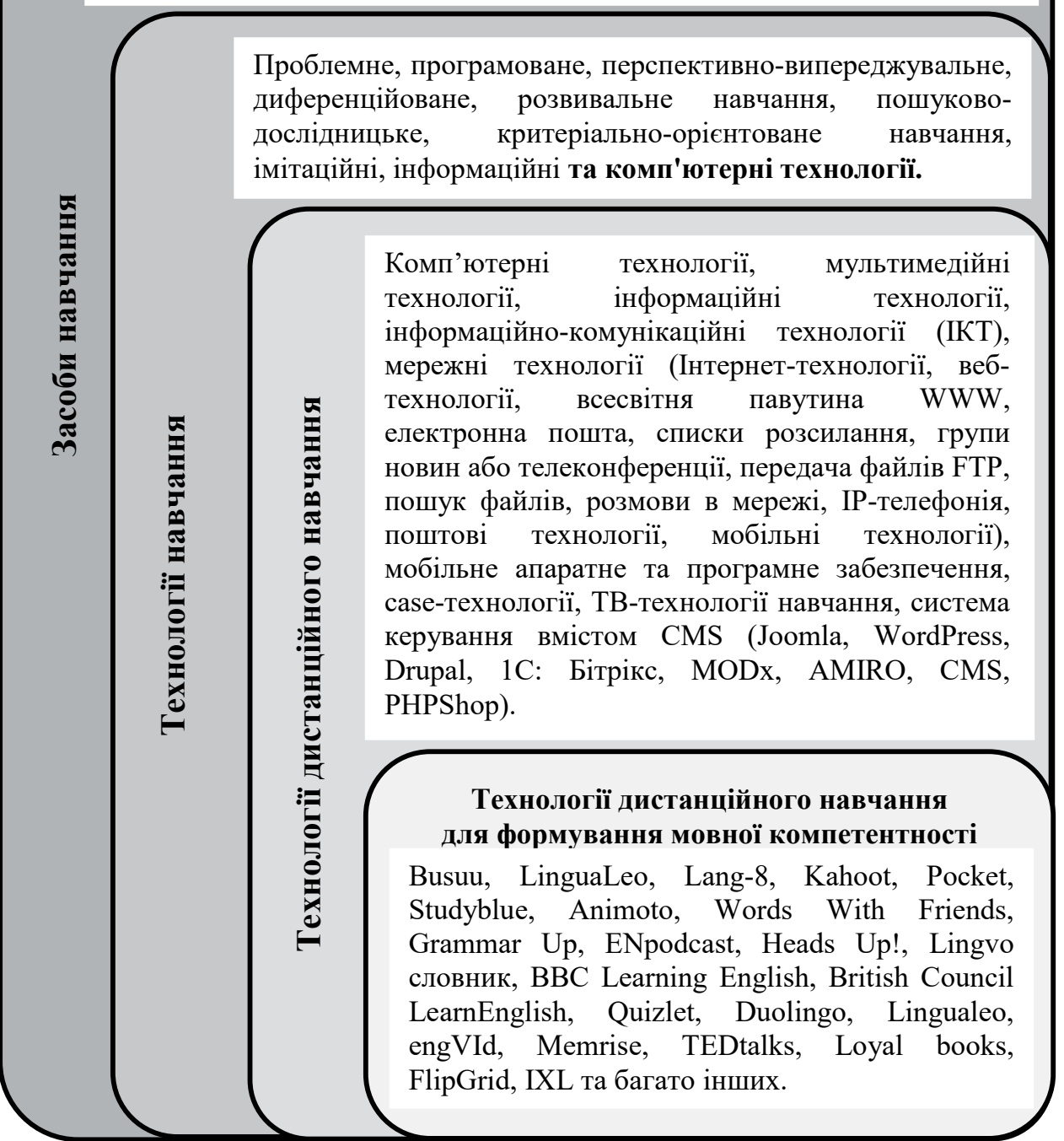

Рис. 1. Співвідношення засобів і технологій дистанційного навчання

\section{Список літератури:}

1. Про затвердження Положення про дистанційне навчання : Наказ Міністерства освіти і науки України № 466 25.04.2013. URL: https://zakon.rada.gov.ua/laws/show/z0703-13\#Text

2. Концепція розвитку дистанційної освіти в Україні (затверджено Постановою МОН України В.Г. Кременем 20 грудня 2000 р.).

3. Організація та використання технологій дистанційного навчання у Збройних Силах України : навч. метод. посіб. / колектив авторів ; за заг. ред. С. М. Салкуцана. Київ : НУОУ, 2017. 124 с.

4. Положення про організацію освітнього процесу в Національній академії Національної гвардії України. 2021. URL: https://nangu.edu.ua/uploads/files/documenty/polozhennya/pologennj\%20pro\%20osvitnu\%20dijlnist\%20v\% 20nangu.pdf

5. Лютий B.М. Стан розробленості проблеми дистаниійного навчання військовослужбовиів інозелним мовали у сучасних науково-педагогічних дослідженнях. Polish science journal (Issue 2(35), 2021). Warsaw: Sp. z o. o. "iScience", 2021. Part 2. P. 111. 
6. Лозова В.І., Троцко Г.В. Теоретичні основи виховання і навчання : Навчальний посібник / Харк. держ. пед. ун-т ім. Г.С. Сковороди. 2-е вид., випр. і доп. Харків : «ОВС», 2002. С. 313.

7. Стефраненко П.В. Технології дистанційного навчання в рамках безперервної освіти військових фахівців: актуалізація особистісної карти компетенцій. Наукові пращі Вищого навчального закладу "Донецький національний технічний університет". Сер. : Педагогіка, психологія і соціологія. 2014. № 1(1). С. $121-125$. URL: http://nbuv.gov.ua/UJRN/Npdntu_pps_2014_1\%281\%29_28

8. Лист МОН України від 02 листопада 2020 р. № 1/9-609 Щодо організації дистанційного навчання. URL: https://mon.gov.ua/ua/npa/shodo-organizaciyi-distancijnogo-navchannya

9. Воронова Н.С. Система формування професійної компетентності майбутніх культурологів засобами цифрових технологій : авторедр. дис ... д-ра пед. наук : 13.00.04. Слов'янськ, 2020. 40 c. URL: http://www.slavdpu.dn.ua/ images/stories/news/specrada/1920211120/Voronova/dis_Voronova.pdf

10. Лукін В.Є. Методика застосування засобів дистанційного навчання у процесі вивчення військово-технічних дисциплін : дис. Київ : Володимир Свгенович Лукін, 2009.

11. Переяславська С.О. Організація самостійної пізнавальної діяльності майбутніх учителів інформатики в умовах застосування мультимедійних елементів дистанційного навчання : автореф. дис. ... канд. пед. наук : 13.00.04 / С. О. Переяславська ; Луган. нац. ун-т ім. Т. Шевченка. Луганськ, 2011. 20 с.

12. Галецький C.M. Формування комунікативної компетентності майбутніх викладачів іноземних мов засобами інформаційнокомунікаційних технологій [Текст] : автореферат дис. канд. пед. наук : 13.00.04. Житомир. держ. ун-т ім. І. Франка. Житомир, 2020. 20 с.

13. Гавриленко О.М. Формування готовності майбутніх учителів іноземних мов до застосування інформаційнокомунікаційних технологій у професійній діяльності : автореф. дис. ... канд. пед. наук : 13.00.04; Кіровогр. держ. пед. ун-т ім. В. Винниченка. Кіровоград, 2011. 20 с. укр.

14. Організація дистанційного навчання в школі : Посібник. Схвалено МОН: лист IM3О № 22.1/12-Г-372. URL: https://mon.gov.ua/storage/app/media/zagalna\%20serednya/metodichni\%20recomendazii/2020/metodichni $\% 20$ recomendazii-dustanciyna\%20osvita-2020.pdf

15. Миколайчук Р.А. Методологічний підхід до визначення ефективності оцінювання рівня володіння іноземною мовою. Актуальні проблели іншомовної підготовки фбахівиів у сфбері національної безпеки. 2015. № 2(17). C. 38-39.

16. Інформаційно-комунікаційні технології у навчанні іноземних мов для професійного спілкування : колективна монографія / Т.І. Коваль, П.Г. Асоянц, Т.М. Каменева, Н.В. Майер, О.С. Синекоп, В.В. Стрілець, А.Ю. Чуфрарлічева; за заг ред. Т.І. Коваль. Київ : Вид. центр КНЛУ, 2012. С. 20.

17. Гнедкова О.О. Використання дистанційного навчання під час контролю знань самостійної роботи студентів мовних спеціальностей ВНЗ. Педагогічний альланах : зб. наук. пр. / [ред. кол. В.В. Кузьменко (голова) та ін.]. Херсон : КВНЗ «Херсонська академія неповної освіти», 2016. Вип. 30. С. 97-105.

18. Романюк C.M. Дистанційне навчання іноземної мови: порівняльний аналіз сучасних платформ та он-лайнсервісів. Вісник Дніпропетровського університету імені Альфреда Нобеля. Серія : Педагогіка і психологія. 2016. № 1. C. 318-325. URL: http://nbuv.gov.ua/UJRN/vduep_2016_1_55

19. Садовський М. Застосування технологій дистанщійного навчання в системі військової освіти. Вісник Національної акаделії Державної прикордонної служби Украӥни. Серія : Педагогіка. 2016. Вип. 6. URL: http://nbuv.gov.ua/UJRN/Vnadped_2016_6_12

20. Організаційні етапи створення дистанційного курсу / Екстрене дистанційне навчання в Україні : Монографрія // За ред. В.М. Кухаренка, В.В. Бондаренка. Харків : Вид-во КП «Міська друкарня», 2020. С. 128-143.

21. Грицук Ю. Проблеми організації дистанційного навчання в умовах карантину в Донбаській національній академії будівництва і архітектури / Екстрене дистанційне навчання в Україні : Монографія / За ред. В.М. Кухаренка, В.В. Бондаренка. Харків : Вид-во КП «Міська друкарня», 2020. С. 176-185.

22. Волинець Д. Креативне та ефективне онлайн-навчання: місія здійсненна! URL: https:/gurt.org.ua/ articles/62959/.

23. Conway C., Harris S., Smith S., Brackett V., Hayes G. Mentoring Students through Digital Learning Experiences. Handbook of Research on Global Issues in Next-Generation Teacher Education, 2016. DOI: 10.4018/978-1-46669948-9.ch012

24. Digital technology. Toolkit Strand. Education Endowment Foundation. EEF, 2019. URL: https://educationendowmentfoundation.org.uk/evidencesummaries/teaching-learning-toolkit/digital-technology/ (accessed 04 May 2021).

25. Wan Ng. New Digital Technology in Education. Conceptualizing Professional Learning for Educators. Springer International Publishing Switzerland, 2015. 197 p. URL: https://link.springer.com/book/10.1007\% 2F978-3-319-05822-1 (accessed 28 April 2021).

26. Гаврілова Л.Г. Система формування професійної компетентності майбутніх учителів музики засобами мультимедійних технологій : дис. ... доктора пед. наук : 13.00.04; НПУ імені М.П. Драгоманова. Київ, 2015.615 с.

27. El Mhouti A., Erradi M., Nasseh A. An Evaluation Model of Digital Educational Resources. International Journal of Emerging Technologies in Learning (iJET). 2013. Vol. 8. Issue 2. DOI: http://dx.doi.org/10.3991/ijet.v8i2.2501

28. Vuorikari R., Koper R. Evidence of Cross-Boundary Use and Reuse of Digital Educational Resources. International Journal of Emerging Technologies in Learning (iJET). 2009. Vol. 4. Issue 4. Pp. 51-56. DOI:10.3991/ijet.v4i4.1028

29. Butcher N. A Basic Guide to Open Educational Resources (OER). United Nations Educational, Scientific and Cultural Organization (UNESCO). 2015. URL: http://oasis.col.org/handle/11599/36

30. Ст. Доунс (St. Downes) [Downes St. Models for Sustainable Open Educational Resources. Interdisciplinary Journal of Knowledge and Learning Objects. 2007. Vol. 3. URL: https://www.learntechlib.org/p/44796/article_44796.pdf

31. Orr D., Rimini M., Van Damme D.Open Educational Resources : A Catalyst for Innovation. Educational Research and Innovation. Paris, France : OECD Publishing, 2015. URL: http://dx.doi.org/10.1787/9789264247543-en

32. Brown M. The NGDLE: We Are the Architects. EDUCAUSE Review. July / August 2017. Pp. 11-18. URL: https://er.educause.edu/-/media/files/articles/2017/7/erm17411.pdf

33. Dobbin G. Exploring the Next Generation Digital Learning Environment: Opportunities and Challenges. EDUCAUSE. 2016. URL: https://library.educause.edu/resources/2016/6/exploring-the-next-generationdigitallearning-environment-opportunities-and-challenges

34. Онлайн-ресурси для вчителів іноземних мов. URL: https://mon.gov.ua/ua/news/na-sajti-mon-rozmishenoperelik-onlajn-resursiv-dlya-vchiteliv-inozemnih-mov 
35. Supporting remote English teaching. 2020. URL: https://mon.gov.ua/storage/app/media/zagalna\%20serednya/ Koordynatsiynyy\%20komitet\%20vchyteliv\%20inozemnykh\%20mov\%20NUSH/2021/02/17/British\%20Council.pdf

36. Українські платформи та ресурси для самоосвіти вчителів. URL: https://edpro.ua/blog/ukrajinski-platformyta-resursy-dlja-samoosvity-vchyteliv

37. Pearson. Ukraine. 2021. URL: https://www.pearson.eu/cee/ukraine/homepage/

38. Інформаційно-комунікаційні технології у навчанні іноземних мов для професійного спілкування : колективна монографрія / Т.І. Коваль, П.Г. Асоянц, Т.М. Каменева, Н.В. Майер, О.С. Синекоп, В.В. Стрілець, А.Ю. Чуфрарлічева; за заг ред. Т.І. Коваль. Київ : Вид. центр КНЛУ, 2012. С. 20.

39. Trubavina, I., Petryshyn, L., Cwer, A., Polacko, J., Monastyrskyi, G., Kultchyckyi, V., Mirshuk, O., and Medvid Yu. Content substantiation of the regional advanced training educational program "Kaizen Technology". SHS Web Conf. Volume 104, Second International Conference on History, Theory and Methodology of Learning (ICHTML 2021). DOI: https://doi.org/10.1051/shsconf/202110403010

40. Положення про дистанщійне навчання в Національному університеті оборони України імені Івана Черняховського : Наказ начальника НУОУ ім. Івана Черняховського від 13.10.2017 року № 278. URL: https://nuou.org.ua/ assets/documents/polo-dn-nduu.pdf

41. Положення про дистанційну форму здобуття повної загальної середньої освіти : Наказ МОН від 08.09.2020 № 1115 .

\section{References:}

1. Ministry of Education and Science. Distance learning manual. (No 466, 2013). URL: https://zakon.rada.gov.ua/ laws/show/z0703-13\#Text

2. Ministry of Education and Science. Distance learning concept development (2000).

3. Salkutsan, S. M. (2017). Orhanizatsiya ta vykorystannya tekhnolohiy dystantsiynoho navchannya u Zbroynykh Sylakh Ukrayiny [Organization and use of distance learning technologies in the Armed Forces of Ukraine], NUOU.

4. The education and training organization at the National Academy of the National Guard of Ukraine. Manual. 2021. URL: https://nangu.edu.ua/uploads/files/documenty/polozhennya/pologennj\%20pro\%20osvitnu\%20dijlnist\%20v\%20 nangu.pdf

5. Liutyi, V. M. (2021). Stan rozroblenosti problemy dystantsiynoho navchannya viys'kovosluzhbovtsiv inozemnym movam u suchasnykh naukovo-pedahohichnykh doslidzhennyakh [The problem of military personnel foreign languages distance learning in modern scientific and pedagogical researches]. Polish science journal, $2(35), 2,111$.

6. Lozova, V. I. \& Troyko, H. V. (2002). Teoretychni osnovy vykhovannya i navchannya [Theoretical bases of education and training]. H.S. Skovoroda KhPU. (2nd ed).

7. Stefanenko, P. V. (2014). Tekhnolohiyi dystantsiynoho navchannya v ramkakh bezperervnoyi osvity viys'kovykh fakhivtsiv: aktualizatsiya osobystisnoyi karty kompetentsiy [Technologies of distance learning in the framework of continuing education of military specialists: actualization of the personal card of competencies]. Donetsk National Technical University researches. Pedagogy, psychology and sociology, 1(1), 121-125. URL: http://nbuv.gov.ua/UJRN/ Npdntu_pps_2014_1\%281\%29_28

8. Ministry of Education and Science mail. Distance learning, 2020. URL: https://mon.gov.ua/ua/npa/shodoorganizaciyi-distancijnogo-navchannya

9. Voronova, N. S. (2020). Systema formuvannya profesiynoyi kompetentnosti maybutnikh kul'turolohiv zasobamy tsyfrovykh tekhnolohiy [The system of formation of professional competence of future culturologists by means of digital technologies] [Doctoral thesis, Donetzk State pedagogical University]. Sloviansk.

10. Lukin, V. Ye. (2009). Metodyka zastosuvannya zasobiv dystantsiynoho navchannya u protsesi vyvchennya viys'kovo-tekhnichnykh dystsyplin [Methods of application of distance learning tools in the process of studying military-technical disciplines] [Doctoral thesis, Ukrainian Engineer-pedagogical Academy]. Kharkiv.

11. Pereyaslavs'ka, S. O. (2011). Orhanizatsiya samostiynoyi piznaval'noyi diyal'nosti maybutnikh uchyteliv informatyky $v$ umovakh zastosuvannya mul'tymediynykh elementiv dystantsiynoho navchannya [Organization of independent cognitive activity of future teachers of informatics in terms of application of multimedia elements of distance learning] [Doctoral thesis, Taras Shevchenko LNU]. Luhans'k.

12. Halets'kyy, S. M. (2020). Formuvannya komunikatyvnoyi kompetentnosti maybutnikh vykladachiv inozemnykh mov zasobamy informatsiyno-komunikatsiynykh tekhnolohiy [Formation of communicative competence of wouldbe teachers of foreign languages by means of information and communication technologies] [Doctoral thesis, Ivan Franko Zhytomyr State University]. Zhytomyr.

13. Havrylenko, O. M. (2011). Formuvannya hotovnosti maybutnikh uchyteliv inozemnykh mov do zastosuvannya informatsiyno-komunikatsiynykh tekhnolohiy u profesiyniy diyal'nosti [Formation of readiness of future teachers of foreign languages to use information and communication technologies in professional activity] [Doctoral thesis, Volodymyr Vinnychenko Kyrovograd State Pedagogic University]. Kyrovograd.

14. Ministry of Education and Science (2020). Orhanizatsiya dystantsiynoho navchannya v shkoli: Posibnyk [Organization of distance learning at school: Manual], no. 22.1/12-Г-372. URL: https://mon.gov.ua/storage/app/media/zagalna\%20 serednya/metodichni\%20recomendazii/2020/metodichni\%20recomendazii-dustanciyna\%20osvita-2020.pdf

15. Mykolaychuk, R. A. (2015). Metodolohichnyy pidkhid do vyznachennya efektyvnosti otsinyuvannya rivnya volodinnya inozemnoyu movoyu [Methodological approach to determining the effectiveness of assessing the level of foreign language proficiency]. Aktual'ni problemy inshomovnoyi pidhotovky fakhivtsiv u sferi natsional'noyi bezpeky, 2(17), 38-39.

16. Koval, T. I., Asoyants, P. G., Kamenyeva, T. M., Mayyer, N. V., Synekop, O. S., Strilets', V. V. \& Chufarlicheva, A. Yu. (Eds.) (2012). Informatsiyno-komunikatsiyni tekhnolohiyi u navchanni inozemnykh mov dlya profesiynoho spilkuvannya [Information and communication technologies in the teaching of foreign languages for professional communication]: Monograph. KNLU print center.

17. Hnyedkova, O. O. (2016). Vykorystannya dystantsiynoho navchannya pid chas kontrolyu znan' samostiynoyi roboty studentiv movnykh spetsial'nostey vyshcyh navcchalnyh zakladiv [The use of distance learning in the control of knowledge of independent work of students of language specialties]. Pedagogical Almanac of Kherson Academy of Incomplete Education, 30, 97-105.

18. Romanyuk, S. M. (2016). Dystantsiyne navchannya inozemnoyi movy: porivnyal'nyy analiz suchasnykh platform ta on-layn-servisiv [Distance learning of a foreign language: a comparative analysis of modern platforms and 
online services]. Bulletin of Alfred Nobel Dnipropetrovsk University. Pedagogy and Psychology, 1, 318-325. URL: http://nbuv.gov.ua/UJRN/vduep_2016_1_55

19. Sadovs'kyy, M. (2016). Zastosuvannya tekhnolohiy dystantsiynoho navchannya v systemi viys'kovoyi osvity [Distance learning technologies in the system of military education]. Bulletin of the National Academy of the State Border Guard Service of Ukraine. Pedagogy, 6. URL: http://nbuv.gov.ua/UJRN/Vnadped_2016_6_12

20. Kukharenko, V.M. \& Bondarenko, V.V. (2020). Orhanizatsiyni etapy stvorennya dystantsiynoho kursu [Organizational stages of creating a distance course]. Emergency distance learning in Ukraine: Monography. Mis'ka drukarnya, 128-143.

21. Hrytsuk, Yu. (2020). Problemy orhanizatsiyi dystantsiynoho navchannya v umovakh karantynu v Donbas'kiy natsional'niy akademiyi budivnytstva i arkhitektury [Problems of organization of distance learning in quarantine in the Donbas National Academy of Civil Engineering and Architecture]. Emergency distance learning in Ukraine: Monography. Mis'ka drukarnya, 176-185.

22. Volynets', D. Kreatyvne ta efektyvne onlayn-navchannya: misiya zdiysnenna! [Creative and effective online learning: mission accomplished]. URL: https://gurt.org.ua/articles/62959/

23. Conway, C., Harris, S., Smith, S., Brackett, V., Hayes, G. (2016). Mentoring Students through Digital Learning Experiences. Handbook of Research on Global Issues in Next-Generation Teacher Education. DOI: 10.4018/9781-4666-9948-9.ch012

24. Digital technology. Toolkit Strand. Education Endowment Foundation. EEF (2019). URL: https://educationendowmentfoundation.org.uk/evidencesummaries/teaching-learning-toolkit/digital-technology/

25. Wan Ng. (2015). New Digital Technology in Education. Conceptualizing Professional Learning for Educators. Springer International Publishing Switzerland. URL: https://link.springer.com/book/10.1007\% 2F978-3-319-05822-1

26. Havrilova, L. H. (2015). Systema formuvannya profesiynoyi kompetentnosti maybutnikh uchyteliv muzyky zasobamy mul'tymediynykh tekhnolohiy [The system of formation of professional competence of future music teachers by means of multimedia technologies] [Doctoral thesis, Mykhailo Dragomanov National Politechnick University]. Kyiv.

27. El Mhouti, A., Erradi, M., Nasseh, A. (2013). An Evaluation Model of Digital Educational Resources. International Journal of Emerging Technologies in Learning (iJET), 8 (2). DOI: http://dx.doi.org/10.3991/ijet.v8i2.2501

28. Vuorikari, R., Koper, R. (2009). Evidence of Cross-Boundary Use and Reuse of Digital Educational Resources. International Journal of Emerging Technologies in Learning (iJET), 4 (4), 51-56. DOI:10.3991/ijet.v4i4.1028

29. Butcher, N. (2015). A Basic Guide to Open Educational Resources (OER). United Nations Educational, Scientific and Cultural Organization (UNESCO). URL: http://oasis.col.org/handle/11599/36

30. St. Downes (2007). [Downes St. Models for Sustainable Open Educational Resources. Interdisciplinary Journal of Knowledge and Learning Objects, 3. URL: https://www.learntechlib.org/p/44796/article_44796.pdf

31. Orr, D., Rimini, M., Van Damme, D. (2015). Open Educational Resources: A Catalyst for Innovation. Educational Research and Innovation. Paris, France: OECD Publishing. URL: http://dx.doi.org/10.1787/9789264247543-en

32. Brown, M. (2017). The NGDLE: We Are the Architects. EDUCAUSE Review, p. 11-18. URL: https://er.educause. edu/-/media/files/articles/2017/7/erm17411.pdf

33. Dobbin, G. (2016). Exploring the Next Generation Digital Learning Environment: Opportunities and Challenges. EDUCAUSE. URL: https://library.educause.edu/resources/2016/6/exploring-the-next-generationdigital-learningenvironment-opportunities-and-challenges

34. Onlayn-resursy dlya vchyteliv inozemnykh mov [Online resources for foreign language teachers]. URL: https://mon.gov.ua/ua/news/na-sajti-mon-rozmisheno-perelik-onlajn-resursiv-dlya-vchiteliv-inozemnih-mov

35. Supporting remote English teaching (2020). URL: https://mon.gov.ua/storage/app/media/zagalna\%20serednya/ Koordynatsiynyy\%20komitet\%20vchyteliv\%20inozemnykh\%20mov\%20NUSH/2021/02/17/British\%20Council.pdf

36. Ukrayins'ki platformy ta resursy dlya samoosvity vchyteliv [Ukrainian platforms and resources for teacher selfeducation]. URL: https://edpro.ua/blog/ukrajinski-platformy-ta-resursy-dlja-samoosvity-vchyteliv

37. Pearson. Ukraine (2021). URL: https://www.pearson.eu/cee/ukraine/homepage/

38. Koval', T. I. (Eds.) (2012). Informatsiyno-komunikatsiyni tekhnolohiyi u navchanni inozemnykh mov dlya profesiynoho spilkuvannya [Information and communication technologies in the teaching of foreign languages for professional communication]: Monograhry.

39. Trubavina, I., Petryshyn, L., Cwer, A., Polacko, J., Monastyrskyi, G., Kultchyckyi, V., Mirshuk, O., \& Medvid Yu. Content substantiation of the regional advanced training educational program "Kaizen Technology". SHS Web Conf. Volume 104, Second International Conference on History, Theory and Methodology of Learning (ICHTML 2021). DOI: https://doi.org/10.1051/shsconf/202110403010

40. Polozhennya pro dystantsiyne navchannya v Natsional'nomu universyteti oborony Ukrayiny imeni Ivana Chernyakhovs'koho [Regulations on distance learning at the Ivan Chernyakhovsky National University of Defense of Ukraine]. (No 278, 2017). URL: https://nuou.org.ua/assets/documents/polo-dn-nduu.pdf

41. Ministry of Education and Science (2020). Polozhennya pro dystantsiynu formu zdobuttya povnoyi zahal'noyi seredn'oyi osvity [Regulations on distance learning of general secondary education]. (No 1115). 